\title{
Tests on composite beams using new connections by adherence
}

*Diógenes, Hidelbrando J. F.1; El Debs, Ana Lúcia H. C.²; Valente, Isabel B. ${ }^{3}$

(1) PhD. Assistant Professor, Civil and Environment Engineering Department, Federal University of Paraíba e-mail: hidelbrando@ct.ufpb.br ${ }^{*}$ Corresponding author LABEME - Campus Universitário I, Castelo Branco, João Pessoa, PB, Brazil. +558399993 3167

(2) PhD. Associated Professor, Structures Department, Engineering School of Sao Carlos, University of Sao Paulo e-mail: analucia@sc.usp.br Trabalhador São Carlense, 400 - São Carlos - SP - Brazil

(3) PhD. Assistant Professor, ISISE, Civil Engineering Department, Engineering School, University of Minho e-mail: isabelv@civil.uminho.pt

Campus de Azurém - 4800-058 Guimarães, Portugal

\begin{abstract}
Cast in place concrete is often the cheapest solution in the context of conventional construction. However, prefabrication presents advantages in terms of execution time, quality of the structural elements and cost. Thus, the association of precast concrete elements and steel sections in a composite element can result in a high quality structure, executed with greater speed and economy of financial and material resources. Currently, steel to concrete composite connections are not completely adapted to prefabricated slabs and the use of connections by adhesion, interlocking and friction seem quite promising. To improve the knowledge in this field, this paper presents the development of full-scale flexural tests of composite beams using new interfaces for these connections, and their results are interpreted and discussed. For comparison purposes, two beams with cast in place slab are tested. A satisfactory behavior in terms of strength is observed, in both cases investigated (cast in place and precast slab), justifying further studies on the subject.
\end{abstract}

Keywords: composite structures; connection by adhesion, interloking and friction; full-scale flexural test.

\section{Keywords chosen from ICE Publishing list}

Composite structures; Beams \& girders; Buildings, structures \& design. 


\section{CONTEXT AND MOTIVATION}

According to the fib Model Code (2013), concrete cast in place is often the cheapest solution in the context of conventional construction. However, prefabrication presents advantages in terms of execution time, noise, traffic interruption, etc. The use of precast concrete in steel and concrete composite structures can offer a higher quality to the structure and can guarantee a greater speed of execution and economy of financial and material resources. Steel and concrete composite structures respond satisfactorily to these needs, since they have steel and concrete elements that can be industrially pre-fabricated, and only lifting and assembly are developed on site.

An example of a successful composite structure is the Petronas Towers in Kuala Lumpur (Malaysia), with 88 floors and $452 \mathrm{~m}$ of high. According to Thornton et al. (1997), cast-in-place high-strength concrete was used in the core, in perimeter columns and also in ring beams to provide high load-carrying ability, stiff lateral load resistance and inherent damping for occupant comfort, all combined in an economical solution. Steel beams on metal deck slabs provide efficient, economical and quickly erected long-span floors, which are easily adaptable to future changes, such as new openings or altered loadings.

In this context, the development of new types of connections is clearly necessary, aiming at the reduction of the construction time and the improvement of the building durability, without increasing the cost of the solution. Connections by adhesion, interlocking, and friction, seem quite promising (Diógenes et al. 2015) in obtaining practical, economical and fast solutions for connections in steel and concrete composite structures.

This paper aims to contribute to the field of connections by adhesion, interlocking and friction, initially studied by Thomann and Lebet (2007) and Papastergiou and Lebet (2014a), by presenting a group of full scale flexural tests of composite beams where the solution developed by Diógenes et al. (2015) for the connection between the steel beam and the precast concrete slab is applied.

Basically, the innovative connection proposed is constituted by an embossed steel plate, welded longitudinally to the upper flange of the steel girder. The deck consists of precast reinforced concrete segments, which are fabricated with an inner rib at the lower part. The surface of this inner rib is roughened by collage of a polka-dot crosswalk automotive plastic (blanket), at the bottom of the formwork. The slab segments are positioned over the steel connector and the void

Diógenes, Hidelbrando J. F., El Debs, Ana Lúcia H. C., Valente, Isabel B. (2018). Tests on composite beams using new connections by adherence. Paper submitted to Structures and Buildings, ICE Publishing, Volume 171, Issue 2, February 2018, Pages 149-165, ISSN 0965-0911 | E-ISSN 1751-7702. 
is filled with injected high strength cement grout. Once the cement grout is cured, the connection is activated and the structural element becomes composite.

The resistance of the connection is sourcing from the shear stress developed in three interfaces: the cement grout-rough concrete interface (interface 01), the embossed steel-cement grout interface (interface 02) and finally the interface between cement grout and the bonding layer (interface 03) (see Figure 2).

According to Papastergiou and Lebet (2014a) and Thomann and Lebet (2007), the advantages of connections by adhesion, interlocking and friction (or Connection by Adherence as Thomann and Lebet (2007) proposes), result from their high resistance to shear, which provides a high level of connection on the composite section. They also present a very stiff behavior, which provides a high level of interaction. This indicates that the initial premise for a composite action, which corresponds to small relative displacements between the interfaces, is possible. Furthermore, the presence of continuous embossed steel plates welded along the upper flange, contributes to:

- a higher strength of the steel element;

- avoid the concentration of stresses in the connection region, thus minimizing problems of durability caused by cracking when compared to headed studs.

Apart from these advantages, it is important to note that the proposed connection by adhesion, interlocking and friction behavior usually presents a reduced ductility (Diógenes et al. 2015).

Thus, by performing the flexural tests on composite beams proposed in this paper, it is intended to extend the knowledge about the new interfaces proposed by Diógenes et al. (2015) in terms of:

- $\quad$ interaction level of the composite section, by comparison with cast-in-place slabs;

- $\quad$ stiffness, strength, and deformation capacity of the designed connectors, when included in a composite beam;

- $\quad$ connection behavior under simulated service conditions, i. e. with the load applied perpendicularly to the connection plane. The slab self-weight, plus the service loads, influence the connection strength, since they create confinement in the connection region. The usually performed Push-out tests do not restrict uplifts displacements.

Diógenes, Hidelbrando J. F., El Debs, Ana Lúcia H. C., Valente, Isabel B. (2018). Tests on composite beams using new connections by adherence. Paper submitted to Structures and Buildings, ICE Publishing, Volume 171, Issue 2, February 2018, Pages 149-165, ISSN 0965-0911 | E-ISSN 1751-7702. 


\section{EXPERIMENTAL PROGRAM}

The next sections will describe the flexural tests on steel and concrete composite beams, performed in the Structures Laboratory at the School of Engineering of Sao Carlos, Brazil. This experimental program complements the experimental study presented by Diógenes et al. (2015).

\subsection{Specimens description and material properties}

Four specimens of composite beams were manufactured using the R and RP-type connectors associated with precast slabs. The R-type and RP-type connectors were studied and assessed by Diógenes et al. (2015) with the objective of finding an easy way to produce shear connections in prefabricated elements and to adapt this new connection technology to the Brazilian market. Considering that a plate similar to BRI 8/10 (the one used by Thomann (2005) and Papastergiou and Lebet (2014a)) was not available in the Brazilian market, alternative types of embossments were tested.

Each connector is characterized by the shape and size of its embossments. The R-type received a mechanical treatment: grooves oriented in 45 degrees in relation to the beam longitudinal axis, with $2 \mathrm{~mm}$ deep and $10 \mathrm{~mm}$ width, in order to improve the mechanism of shear stress transfer (Figure 3.a).

A variation of the R-type connector was also proposed. The RP-type connector (Figure 3.b) results from the combination of two ideas, the Perfobond connector proposed by Leonhardt et al. (1987) and the R connector proposed by Thomann (2005). It is intended that the holes can generate a "dowel effect" and increase the connector's strength.

The mechanical treatment was performed on the connector surface, and in addition, a roughness was designed in the concrete blocks in order to improve the transfer of shear stresses between the involved interfaces. Figure 4 shows the surface obtained on the reinforced concrete precast slab and presents the sequence of grouting process. More details about the connection surfaces are presented in Diógenes et al. (2015)

For comparison purposes, two composite beam specimens employing RP-type connectors were also produced, using cast in-place slabs. Therefore, a total of six specimens were prepared for testing. Table 1 presents a summary of geometric properties on these specimens.

Diógenes, Hidelbrando J. F., El Debs, Ana Lúcia H. C., Valente, Isabel B. (2018). Tests on composite beams using new connections by adherence. Paper submitted to Structures and Buildings, ICE Publishing, Volume 171, Issue 2, February 2018, Pages 149-165, ISSN 0965-0911 | E-ISSN 1751-7702. 
The steel profile W360 $\times 44$ was used to guarantee that failure occurred in the beam-slab connection and to maximize the shear stresses in the connection. The neutral axis of the composite cross section was intentionally located in the beam-slab interface level. In an analytical approach, according to the Brazilian code NBR 8800 (2008), the composite section (Figure 2) should achieve $503.01 \mathrm{kN}$.m of bending moment strength. These calculations considered a full interaction in the shear connection. The flexural tests were performed with a simply supported beam and three point loading configuration. Monotonic load steps were set in the middle span and applied with manual control. FIGURE CAPTIONS

Figure 1 presents an overview of the test setup.

The test results were analyzed in pairs, grouped for each type of analyzed embossment or slab type. Specimens VM-03, VM-04, VM-05 and VM-06 consist of a steel beam with an embossed straight connector ( $R$ type in VM-03 and VM-04 and RP-type in VM-05 and VM-06) welded on the top flange, assembled with a precast reinforced concrete slab (see Figure 2.a). The connection between these elements is obtained by grouting.

The arrangement of reinforcement that was used in precast slabs, was also used in cast in place slabs i.e. with no overlapping of rebars through the connector (Figure 3.c). The bars of positions $\mathrm{N} 2$ and N3 have a diameter of $8.0 \mathrm{~mm}$, while the stirrups possess $5.0 \mathrm{~mm}$ diameter and are $20 \mathrm{~cm}$ spaced. Bars with $12.5 \mathrm{~mm}$ diameter are welded on the surface of the steel beam top flange, in order to serve as spacers and work as shear keys (Figure 3.d).

To produce the cast in place specimens, VM-01 and VM-02, a timber formwork was prepared and traditional methods of concreting were applied (Figure 4).

Table 2 summarizes the mechanical properties obtained during the caracterization tests performed on the materials used in the composite beams: HPM (high performance mortar) used in the grouting process, concrete for the slab, and structural steel for the metallic beams and connectors. More details about the manufacturing procedures associated with HPM can be found in (Diógenes et al. 2015). The values of the reinforcement properties presented in Table 2 correspond to the nominal values provided by the manufacturer.

Diógenes, Hidelbrando J. F., El Debs, Ana Lúcia H. C., Valente, Isabel B. (2018). Tests on composite beams using new connections by adherence. Paper submitted to Structures and Buildings, ICE Publishing, Volume 171, Issue 2, February 2018, Pages 149-165, ISSN 0965-0911 | E-ISSN 1751-7702. 


\title{
2.2 Instrumentation and test procedures
}

\author{
FIGURE CAPTIONS
}

Figure 1 presents an overview of the flexural test setup. During the flexural test, a preliminary load of $50 \mathrm{kN}$ was applied at the beam mid-span, in order to test the experimental setup and avoid occasional accommodation or settlements. Afterwards, vertical loading was applied with a rate of $50 \mathrm{kN} / \mathrm{min}$, until reaching the plasticization of composite beam specimen.

Eleven resistive transducers were used to measure slip, uplift and vertical displacement of the tested composite beams (Figure 6). Slip and uplift measurements were taken in both sides of the specimens, at the support region. Vertical displacement was measured in the following positions: at the mid-span, at $0.50 \mathrm{~m}$ distance from de mid-span, and near the supports. These last measurements were set to control some support displacement.

Strain gauges were positioned in the mid and thirds of span of all the tested specimens, as can be seen in Figure 7.a and Figure 7.b. It's noteworthy that, for the reinforcement bars, gauges were positioned just in the mid-span (Figure 7.c).

\section{$3 \quad$ RESULTS AND DISCUSSION}

The next sections will describe the results obtained in flexural tests performed on steel and concrete composite beams and also the preliminary numerical study developed with the intention of supporting the experimental study.

It is to be noted that some of the VM-04' results are shown, but not all of them will be considered in the discussion, because this specimen suffered web crippling phenomena in the support region, caused by the absence of web stiffeners. In the remaining specimens, it was possible to use web stiffeners in the support region.

\subsection{Preliminary numerical model}

During the monotonic tests, the maximum load of the composite beam was measured and the yielding limit of the steel section was identified. In order to support the analysis of the experimental results, a preliminary three-dimensional numerical FEM simulation was developed using the computational package Fx + Diana ${ }^{\circledR}$ v. 9.4.4 (Figure 8).

Diógenes, Hidelbrando J. F., El Debs, Ana Lúcia H. C., Valente, Isabel B. (2018). Tests on composite beams using new connections by adherence. Paper submitted to Structures and Buildings, ICE Publishing, Volume 171, Issue 2, February 2018, Pages 149-165, ISSN 0965-0911 | E-ISSN 1751-7702. 
In the numerical model, the connection behaviour was simulated with a linear interface model. The linear interface model requires basically the tangential stiffness $\left(K_{\mathrm{t}}\right.$ in $\left.\mathrm{N} / \mathrm{mm}^{3}\right)$ and the normal stiffness $\left(K_{\mathrm{n}}\right.$ in $\left.\mathrm{N} / \mathrm{mm}^{3}\right)$ at the finite elements interface. Thus, to simulate a full interaction situation, an extremely high value of tangential stiffness is adopted, whereas in the opposite case, absence of interaction, a value close to zero was adopted for the mentioned parameter. The linear interface model chosen encompasses interfaces 01,02 and 03 previously described in section 1.

The resistance of each composite cross section components (RC slab and I-steel beam) was estimated separately. The aim was to evaluate their strength levels in the following extreme situations: the complete absence of interaction between the cross section components (no interaction) and full interaction (Figure 9). This evaluation was performed in order to guide the discussion related to the level of interaction provided by the connection proposed.

\subsection{Failure modes}

The results previously obtained in push-out tests, and reported in Diógenes et al. (2015), indicate that in connections by adhesion, interlocking and friction, the beginning of rupture is a fragile and irreversible process, and a direct function of the slip value. In these tests, the behavior of the connection is usually evaluated by comparing the load applied and the slip measured at the interface between the concrete slab and the steel beam. It was observed that the post-peak phase of the load-slip curve is predominantly descendent, with a slip-softening evolution. The behavior is similar in all the connectors tested.

In the beam prototypes built with precast slabs, the connection damage begins when the vertical load applied is around $450 \mathrm{kN}$ (Figure 10). At this level of load, the slip between the interfaces is initiated (Figure 11) and simultaneously, the first cracks begin to appear on the bottom of the concrete slab, at the beam mid-span (Figure 12.a). These cracks are oriented perpendicularly to the beam longitudinal axis. An average maximum load value of about of $590 \mathrm{kN}$ is obtained, which corresponds to the moment when the composite section reaches the plastic plateau, as can be seen in Figure 10. This load value provokes a bending moment of $486 \mathrm{kN}$.m, which is close to the value presented in section 2.1 for the nominal plastic bending moment of the composite section considering full interaction $(503.01 \mathrm{kN} . \mathrm{m})$, calculated according to the Brazilian code NBR 8800 (2008).

Diógenes, Hidelbrando J. F., El Debs, Ana Lúcia H. C., Valente, Isabel B. (2018). Tests on composite beams using new connections by adherence. Paper submitted to Structures and Buildings, ICE Publishing, Volume 171, Issue 2, February 2018, Pages 149-165, ISSN 0965-0911 | E-ISSN 1751-7702. 
This result indicates that the composite beam goes into the plastic domain. Results from the strain of the steel section bottom flange and the reinforcement bars endorse this hypothesis and will be presented in section 3.5 .

As mentioned, the first tensile cracks appear on the concrete slab when vertical displacement in the beam mid-span is around $10 \mathrm{~mm}$ for specimens VM-01 and VM-02, and $5 \mathrm{~mm}$ for prototypes VM-03 to VM-06 (see Figure 10 and Figure 11). The initiation of cracking is possibly the limit at which the interaction of the composite section ceases to be complete, because damage in the shear connection occurs.

It should be noted that, according to Diógenes et al. (2015), for a slip value of about $6 \mathrm{~mm}$, the connection still has a load capacity of around $210 \mathrm{kN} / \mathrm{m}$ for the R-type connector and $245 \mathrm{kN} / \mathrm{m}$ for the RP type connector. This indicates that despite of the composite beam plasticizing, the connection still has strength, as can be noted by comparing Figure 9 and Figure 10, where the maximum load obtained in the numerical model for the beam with null interaction is around 450 $\mathrm{kN}$ and the maximum load applied to the beams tested with precast slabs is around $600 \mathrm{kN}$. It was not possible to detect a significant influence of the connector type, R or RP, on the slip evolution. In general, all specimens exhibited some asymmetry in the slip behavior, as one side of the specimen slides more than the opposite one.

It is noteworthy that, for specimens VM-01 and VM-02 (with cast in place slab), the beginning of slip is intertwined with damage on the beam-slab connection, followed by the beginning of the slab cracking and also the plasticization of the steel section. This damage in the shear connection is identified with a sudden loss of load capacity (Figure 10) and a sudden increase of slip (Figure 11 ), when the load applied is around $700 \mathrm{kN}$. Before the connection failure, there is a high degree of interaction on the composite section.

The comparison between Figure 9 and Figure 10 shows a full interaction situation for specimens VM-01 and VM-02 until the maximum load is attained. It also confirms that the sudden loss of load capacity results from damage in the shear connection. The identification of the connection residual strength is not possible, since no push-out tests with cast in-place slabs were performed in (Diógenes et al. 2015), although it is probably higher than the one measured in specimens with precast slabs (VM-03, VM-05 and VM-06).

In a general way, it is understood that all specimens reached a high degree of damage on the composite section (Figure 12). The concrete slab showed cracking near the force application

Diógenes, Hidelbrando J. F., El Debs, Ana Lúcia H. C., Valente, Isabel B. (2018).

Tests on composite beams using new connections by adherence.

Paper submitted to Structures and Buildings, ICE Publishing, Volume 171, Issue 2, February 2018, Pages 149-165, ISSN 0965-0911 | E-ISSN 1751-7702. 
point, with significant width, but without crushing the compressed region, and the steel beam achieved the plasticization without presenting localized modes of failure.

\subsection{Maximum flexural strength and degree of interaction}

The values of maximum load and flexural stiffness, obtained in the bending tests performed on composite beam specimens are presented in Table 3. All the results refer to the beam mid-span. The specimens with cast in place slabs, VM-01 and VM-02, present the highest load capacity. Comparing the maximum load measured in VM-03, VM-05 and VM-06, it can be inferred that, the presence of the holes in the RP-type connectors did not influence significantly neither the flexural stiffness nor the load capacity of the specimens, although the use of RP-type connectors allowed higher vertical displacements, resulting in a more ductile behavior. This behavior can be verified by comparing the results presented in Table 3 and Figure 11.

Slip at the beams' supports reached the highest values in specimens VM-03, VM-05 and VM-06. The mentioned behavior is the result of a lower level of interaction between the steel beam and the concrete slab when compared to the cast in place specimens (VM-01 and VM-02).

As previously described, the numerical simulation presented in Figure 9, associated with the results presented so far, indicate that the specimens with cast in place slab (VM-01 and VM-02) showed a full interaction at the composite section until the maximum load. On average, these prototypes attained a maximum load of $736.02 \mathrm{kN}$, which is close to the value obtained in the numerical simulation, considering complete interaction.

Therefore, if it is considered that the degree of interaction is a direct function of maximum resistance of the specimen, then the specimens with precast slabs (VM-03, VM-04, VM-05 and VM-06) show a degree of interaction of $79.1 \%(582.92 \mathrm{kN} / 736.02 \mathrm{kN}=0.791)$ for type RP specimens and $76.7 \%$ for type $\mathrm{R}(564.67 \mathrm{kN} / 736.02 \mathrm{kN}=0.767)$.

Still on the discussion about the degree of interaction, when comparing these values with the nominal resistant bending moment calculated from the Brazilian code NBR 8800 (2008), it can be considered that, for design purposes, full interaction for specimens with cast in place slabs is adequate. For specimens with precast slabs, 95.6\% (480.91 kN.m / 503.01 kN.m) of interaction for type RP specimen, and 92.6\% (465.83 kN.m / $503.01 \mathrm{kN} . \mathrm{m})$ of interaction for type R specimens (see Table 3 to check values on maximum bending moment).

Diógenes, Hidelbrando J. F., El Debs, Ana Lúcia H. C., Valente, Isabel B. (2018). Tests on composite beams using new connections by adherence. Paper submitted to Structures and Buildings, ICE Publishing, Volume 171, Issue 2, February 2018 , Pages 149-165, ISSN 0965-0911 | E-ISSN 1751-7702. 


\subsection{Uplift and slip}

Concerning to the uplift $\times$ slip behavior, specimens VM-01 and VM-02 presented some asymmetry, i.e., only one side of the specimen slipped, and therefore it was not possible to provide a consistent average uplift $\times$ slip curves, due to the brittle rupture of the connection. For the rest of the specimens, it was possible to extract the average uplift $\times$ slip curve, once the rupture was more ductile (Figure 13.b). Figure 13.b provides insight on the connection "dilatancy".

Comparing this result to the push-out tests performed by Diógenes et al. (2015), it is clear that the uplift is lower and did not reach values above $0.5 \mathrm{~mm}$, while in Diógenes et al. (2015), uplift values are greater than $1.0 \mathrm{~mm}$ for the same value of slip. A smaller uplift presented by specimens of composite beam, must be associated with the action of self-weight of the slab and the direction of the load application, which certainly contributes to increase the normal stiffness. However, the uplift value of $0.5 \mathrm{~mm}$ still corresponds to a high level of connection damage, as can be seen in the push-out tests reported in Diógenes et al. (2015).

\subsection{Strain gauges results}

It is noteworthy that, for all specimens, strain values greater than $0.2 \%$ were identified only after the specimen achieved its maximum strength.

As expected, the reinforcement bars positioned nearest to the connector showed the highest strain values. Special attention should be given to position N3 which showed, in general, higher strain values for lower levels of vertical displacement (see gauge E-05 in Figure 7.b).

This observation is consistent with the cracking identified in the composite beam cross section (marked red in Figure 12.c and Figure 12.d), for both the prototypes with cast in place slab and the prototypes with precast slab. Diógenes et al. (2015) observed similar cracking configuration in the push-out tests with slabs of plain concrete.

The lower reinforcement bars (gauges E-01 and E-02) achieved the steel yielding limit, however the upper slab reinforcements (gauge E-06) showed no significant strain values, indicating that, in fact, there was no concrete crushing.

Figure 14 shows a clear plasticization of the bottom flange of all the tested beams, since the steel yield limit is always achieved.

Diógenes, Hidelbrando J. F., El Debs, Ana Lúcia H. C., Valente, Isabel B. (2018). Tests on composite beams using new connections by adherence. Paper submitted to Structures and Buildings, ICE Publishing, Volume 171, Issue 2, February 2018, Pages 149-165, ISSN 0965-0911 | E-ISSN 1751-7702. 


\section{CONCLUSIONS}

The shear connection proposed in the presented work allowed all the tested beam specimens to achieve a composite section with high degree of interaction and an elevated strength.

The specimens with cast in place slabs (VM-01 and VM-02) present the highest load capacity. The numerical simulation performed and the experimental results indicate that the specimens with cast in place slab showed a full interaction at the composite section until the maximum load. On average, these prototypes attained a maximum experimental load that is close to the value obtained in the numerical simulation, considering complete interaction.

For the specimens with cast in place slabs, it can be inferred that there was not a complete interaction between the concrete slab and the steel section. In simplified terms, up to $76 \%$ of interaction was calculated, based on the experimental results measured.

This result is very relevant in the context of a connection exclusively obtained by adhesion, interlocking and friction.

Slip at the beams' supports reached the highest values in specimens with precast slabs. The mentioned behavior is the result of a lower level of interaction between the steel beam and the concrete slab when compared to the cast in place specimens. When comparing the maximum load measured in specimens fabricated with precast slabs (VM-03, VM-04, VM-05 and VM-06), it can be inferred that the presence of the holes in the RP-type connectors did not influence significantly neither the flexural stiffness nor the load capacity of the specimens, although the use of RP-type connectors allowed higher vertical displacements, resulting in a more ductile behavior. The same result was previously obtained in push-out tests performed by Diógenes et al. (2015).

However, the holes presence in the connector allows for the reinforcement passage when necessary. It has been previously demonstrated that the presence of transversal reinforcement is able to increase the connection strength and/or ductility ((Valente \& Cruz 2009), (Veríssimo et al. 2006). Thus, since it does not cause an excessive extra cost in the production, it is desirable that the holes are present.

Finally, it is believed that connections by adhesion, interlocking and friction are a viable option for structural engineers. More research should be carried out, especially related to the individual characterization of the different interfaces used, the connection fatigue behavior and the response under long-term loadings.

Diógenes, Hidelbrando J. F., El Debs, Ana Lúcia H. C., Valente, Isabel B. (2018). Tests on composite beams using new connections by adherence. Paper submitted to Structures and Buildings, ICE Publishing, Volume 171, Issue 2, February 2018, Pages 149-165, ISSN 0965-0911 | E-ISSN 1751-7702. 


\section{ACKNOWLEGMENTS}

The authors are grateful to the Structures Laboratory of the Department of Structural Engineering (LE-EESC), the Brazilian federal agency CAPES, the Foundation for Research Support of the state of Sao Paulo (FAPESP), Brazil, and the University of Minho, in Portugal, for the international collaboration.

\section{REFERENCES}

ABNT - ASSOCIAÇÃO BRASILEIRA DE NORMAS TÉCNICAS., 2008. NBR 8800: Design of steel and composite structures for buildings, Rio de Janeiro.

Diógenes, H.J.F., El Debs, A.L.H.C. \& Valente, I.B., 2015. Experimental analysis of new interfaces for connections by adhesion, interlocking and friction. Journal of Constructional Steel Research, 110, pp.170-181. Available at:

http://www.sciencedirect.com/science/article/pii/S0143974X15000887 [Accessed April 13, 2015].

Fib - Fédération internationale du Béton, 2013. fib Model Code for Concrete Structures 2010, Lausanne.

Leonhardt, F. et al., 1987. Neues, vorteilhaftes Verbundmittel für Stahlverbund-Tragwerke mit hoher Dauerfestigkeit. Beton- und Stahlbetonbau, 82(12), pp.325-331. Available at: http://doi.wiley.com/10.1002/best.198700500 [Accessed February 24, 2014].

Papastergiou, D. \& Lebet, J.-P., 2014a. Design and experimental verification of an innovative steel-concrete composite beam. Journal of Constructional Steel Research, 93, pp.9-19. Available at: http://linkinghub.elsevier.com/retrieve/pii/S0143974X1300299X [Accessed February 15, 2014].

Papastergiou, D. \& Lebet, J.-P., 2014b. Design and experimental verification of an innovative steel-concrete composite beam. Journal of Constructional Steel Research, 93, pp.9-19. Available at: http://www.sciencedirect.com/science/article/pii/S0143974X1300299X [Accessed August 13, 2015].

Thomann, M., 2005. Connexions par adhérence pour les ponts mixtes acier-béton. PhD Thesis . École Polytechnique Fédérale de Lausanne.

Thomann, M. \& Lebet, J.-P., 2007. The modelling of an embossed steel-to-cement paste confined

Diógenes, Hidelbrando J. F., El Debs, Ana Lúcia H. C., Valente, Isabel B. (2018). Tests on composite beams using new connections by adherence. Paper submitted to Structures and Buildings, ICE Publishing, Volume 171, Issue 2, February 2018, Pages 149-165, ISSN 0965-0911 | E-ISSN 1751-7702. 
interface loaded in shear. Journal of Constructional Steel Research, 63(5), pp.639-646.

Available at: http://linkinghub.elsevier.com/retrieve/pii/S0143974X06001659 [Accessed April 7, 2012].

Thornton, C.H., Hungspruke, U. \& Joseph, L.M., 1997. Design of the world's tallest buildingsPetronas Twin Towers at Kuala Lumpur City Centre. The Structural Design of Tall Buildings, 6(4), pp.245-262. Available at: http://dx.doi.org/10.1002/(SICI)1099-

1794(199712)6:4<245::AID-TAL103>3.0.CO.

Valente, I.B. \& Cruz, P.J.S., 2009. Experimental analysis of shear connection between steel and lightweight concrete. Journal of Constructional Steel Research, 65(10-11), pp.1954-1963.

Available at: http://www.sciencedirect.com/science/article/pii/S0143974X09001357 [Accessed February 21, 2014].

Veríssimo, G.S. et al., 2006. Projeto e análise experimental de um conector de cisalhamento em chapa de aço dentada para estruturas mistas de aço e concreto. Revista Sulamericana de Engenharia Estrutural, 3(3).

Diógenes, Hidelbrando J. F., El Debs, Ana Lúcia H. C., Valente, Isabel B. (2018).

Tests on composite beams using new connections by adherence.

Paper submitted to Structures and Buildings, ICE Publishing, Volume 171, Issue 2, February 2018, Pages 149-165, ISSN 0965-0911 | E-ISSN 1751-7702. 


\section{FIGURE CAPTIONS}

Figure 1 - Overview of the composite beam test.

Figure 2 - Cross section of standard specimen: (a) VM-03 to VM-06; (b) VM-01 and VM-02; (c) Interfaces detail.

Figure 3 - Shear connections tested: (a) Connector R-type; (c) Connector RP-type; (c) Reinforcement arrange; (d) Spacers simulating shear keys.

Figure 4 - (a) printed roughness; (b) grouting process; (c) positioning of steel beam; (d) clamping.

Figure 5 - Formwork for specimens VM-01 and VM-02.

Figure 6 - Transducers position.

Figure 7 - Strain gauges positions: (a) Specimens VM-01 and VM-02; (b) Specimens VM-03, VM04, VM-05 and VM-06; (c) Strain gauges of reinforcements at the mid-span of beam.

Figure 8 - Preliminary numerical model.

Figure 9 - Preliminary numerical study where both the degree of interaction at the composite section and the resistance of isolated elements are considered.

Figure 10 - Specimens results: Load $\times$ Displacement, at the beam's mid-span.

Figure 11 - Load (applied at mid span) x Slip (measured in support).

Figure 12 - Post-peak configuration of the elements of composite section: a) Slab Cracking; (b) Detachment of the protective paint on the bottom flange; (c) Connection region detail - Specimens with precast slab; (d) Connection region detail - Prototype with cast in place slab.

Figure 13 - (a) Slip versus Vertical displacement (mid-span); (b) Slip versus Uplift (end supports) Figure 14 - Steel beam strains - upper and bottom flange.

\section{TABLE CAPTIONS}

Table 1 - Summary of geometrical characteristics of composite beams specimens.

Table 2 - Mechanical properties of used materials.

Table 3 - Maximum flexural strength.

Diógenes, Hidelbrando J. F., El Debs, Ana Lúcia H. C., Valente, Isabel B. (2018).

Tests on composite beams using new connections by adherence.

Paper submitted to Structures and Buildings, ICE Publishing, Volume 171, Issue 2, February 2018,

Pages 149-165, ISSN 0965-0911 | E-ISSN 1751-7702. 


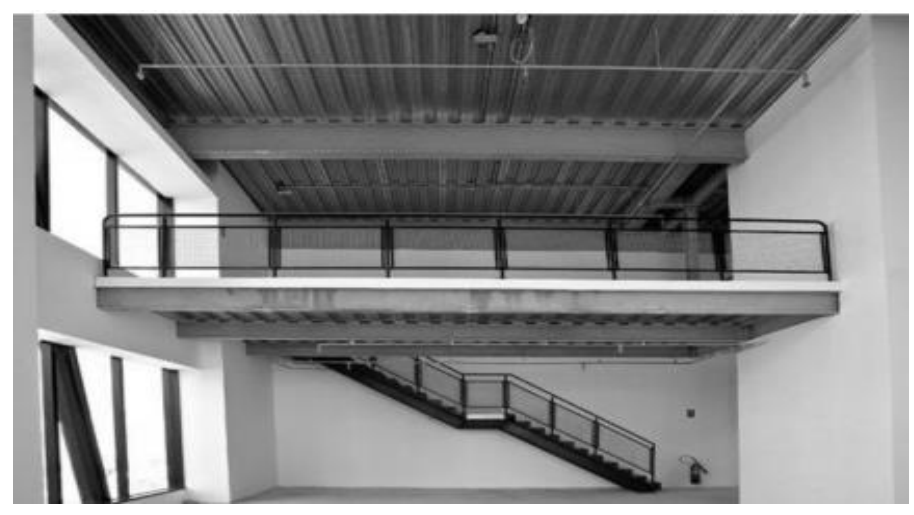

(a)

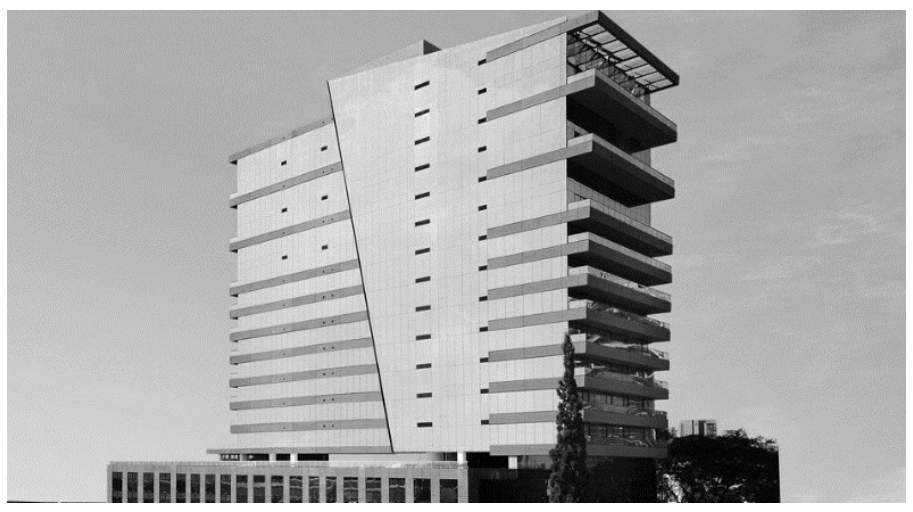

(b)

Figure 1 - The One Faria Lima: (a) Composite structure detail. (b) Building façade.

Diógenes, Hidelbrando J. F., El Debs, Ana Lúcia H. C., Valente, Isabel B. (2018).

Tests on composite beams using new connections by adherence.

Paper submitted to Structures and Buildings, ICE Publishing, Volume 171, Issue 2, February 2018,

Pages 149-165, ISSN 0965-0911 | E-ISSN 1751-7702. 


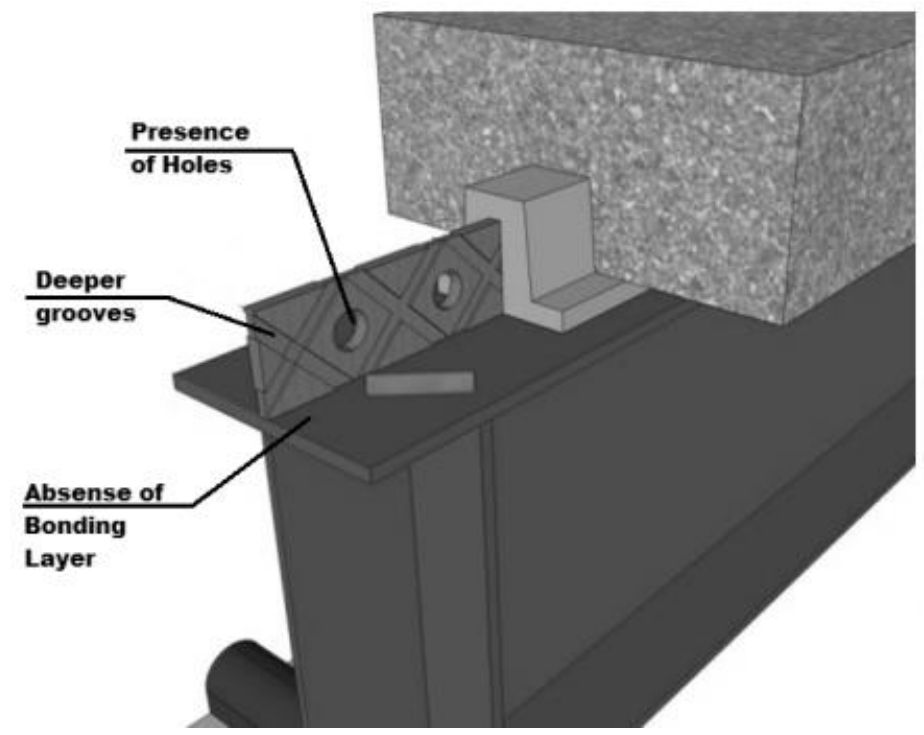

Figure 2 - Innovative connection proposed.

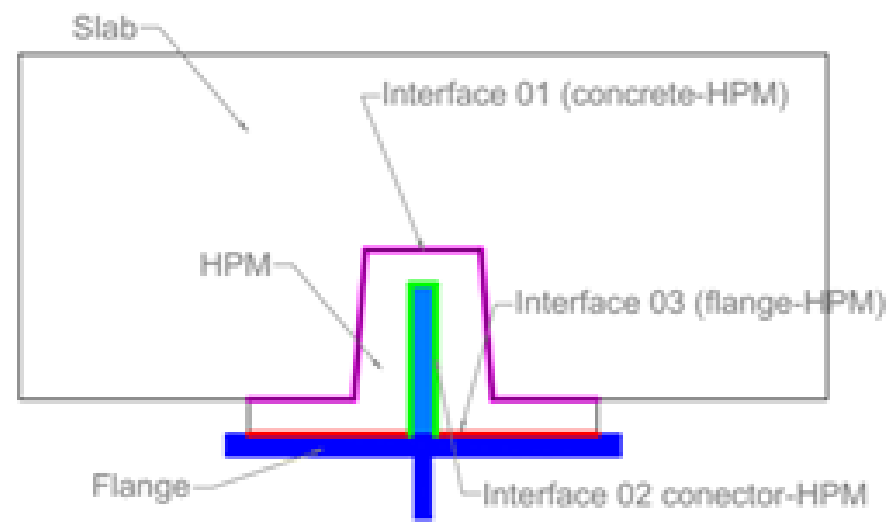

Figure 3 - Interfaces detail.

Diógenes, Hidelbrando J. F., El Debs, Ana Lúcia H. C., Valente, Isabel B. (2018).

Tests on composite beams using new connections by adherence.

Paper submitted to Structures and Buildings, ICE Publishing, Volume 171, Issue 2, February 2018,

Pages 149-165, ISSN 0965-0911 | E-ISSN 1751-7702. 


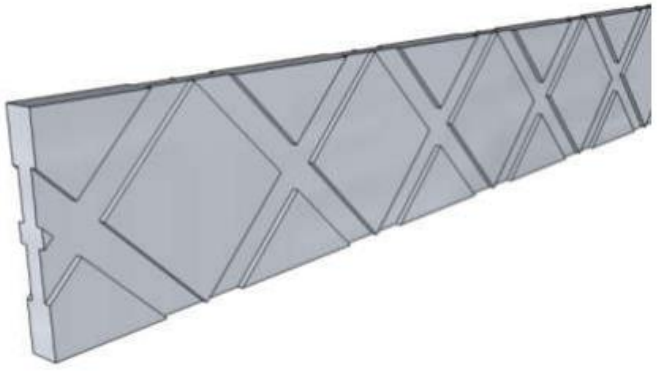

(a)

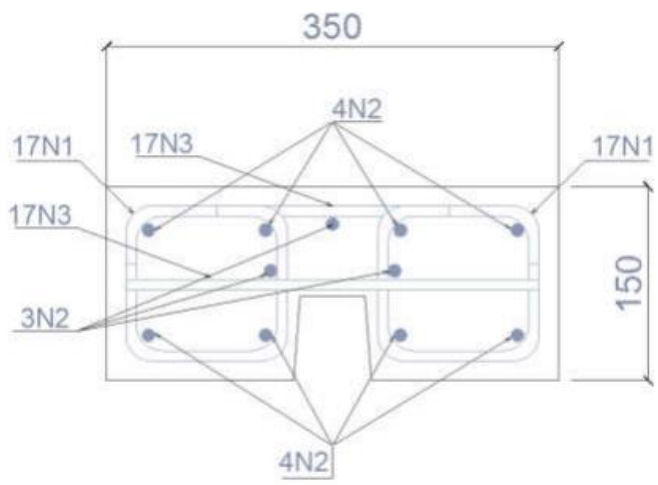

(c)

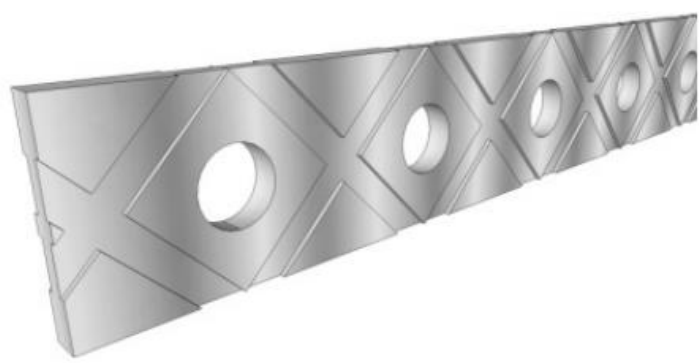

(b)

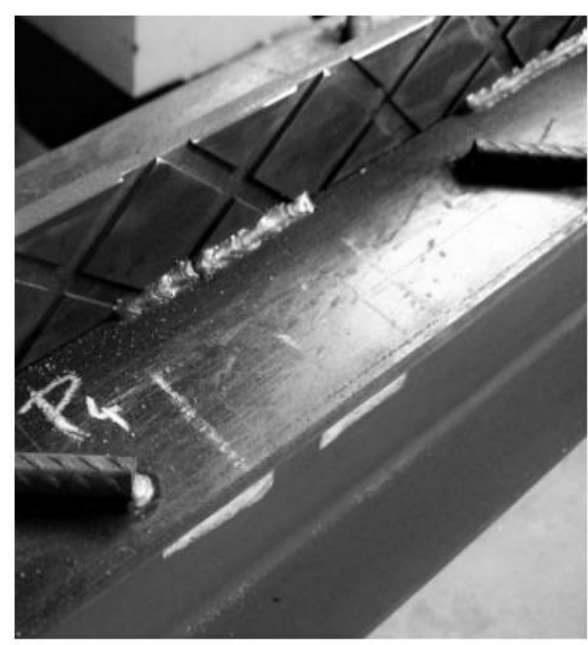

(d)

Figure 4 - Shear connections tested: (a) Connector R-type; (c) Connector RP-type; (c) Reinforcement arrange; (d) Spacers simulating shear keys.

Diógenes, Hidelbrando J. F., El Debs, Ana Lúcia H. C., Valente, Isabel B. (2018).

Tests on composite beams using new connections by adherence.

Paper submitted to Structures and Buildings, ICE Publishing, Volume 171, Issue 2, February 2018, Pages 149-165, ISSN 0965-0911 | E-ISSN 1751-7702. 


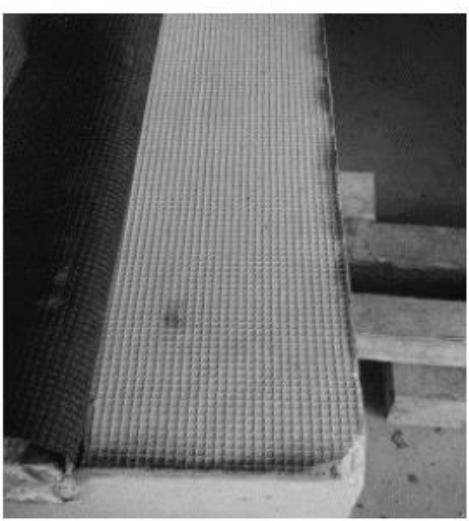

(a)

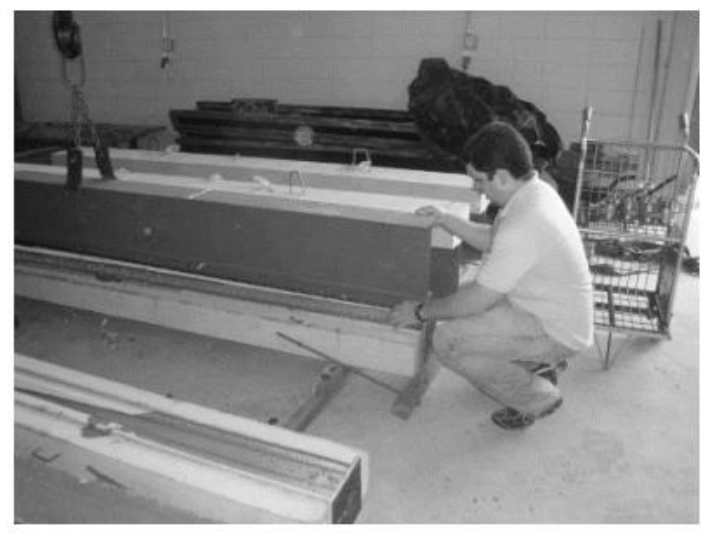

(c)

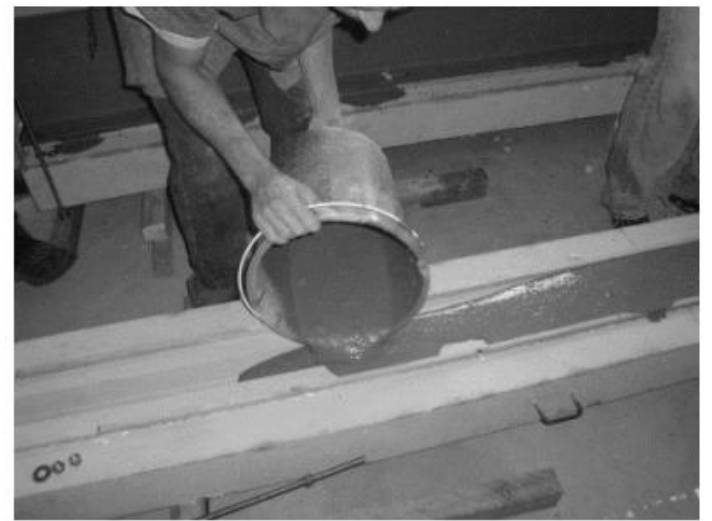

(b)

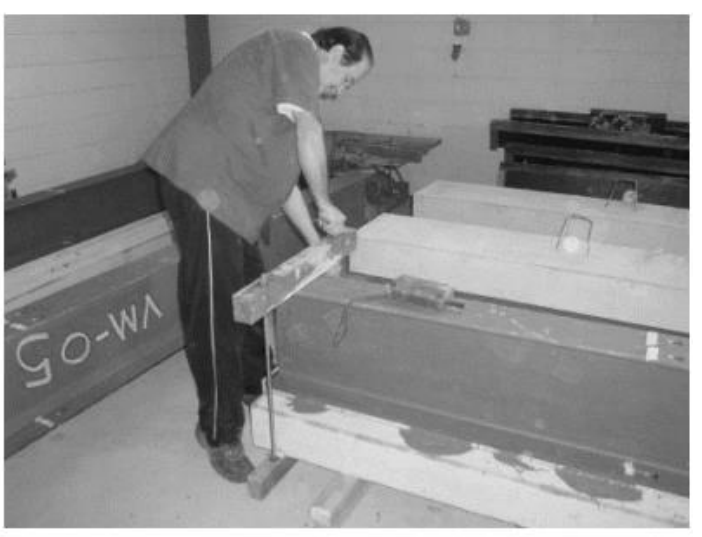

(d)

Figure 5 - (a) printed roughness; (b) grouting process; (c) positioning of steel beam; (d) clamping.

Diógenes, Hidelbrando J. F., El Debs, Ana Lúcia H. C., Valente, Isabel B. (2018).

Tests on composite beams using new connections by adherence.

Paper submitted to Structures and Buildings, ICE Publishing, Volume 171, Issue 2, February 2018,

Pages 149-165, ISSN 0965-0911 | E-ISSN 1751-7702. 


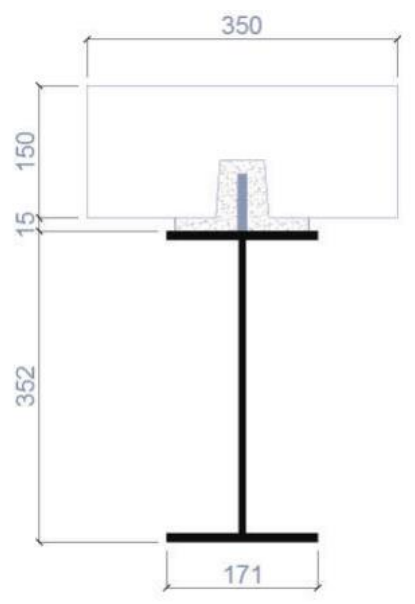

(a)

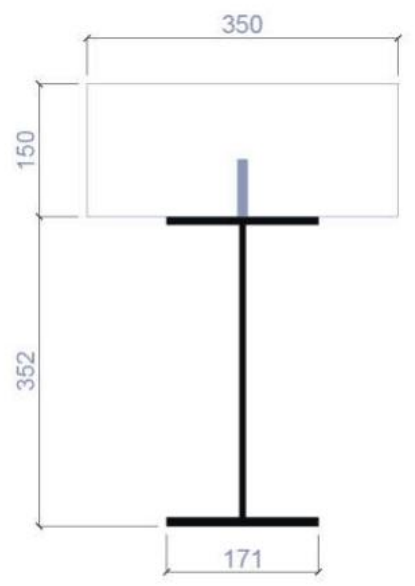

(b)

Figure 6 - Cross section of specimens: (a) Using precast slabs; (b) Using cast-in-place slabs

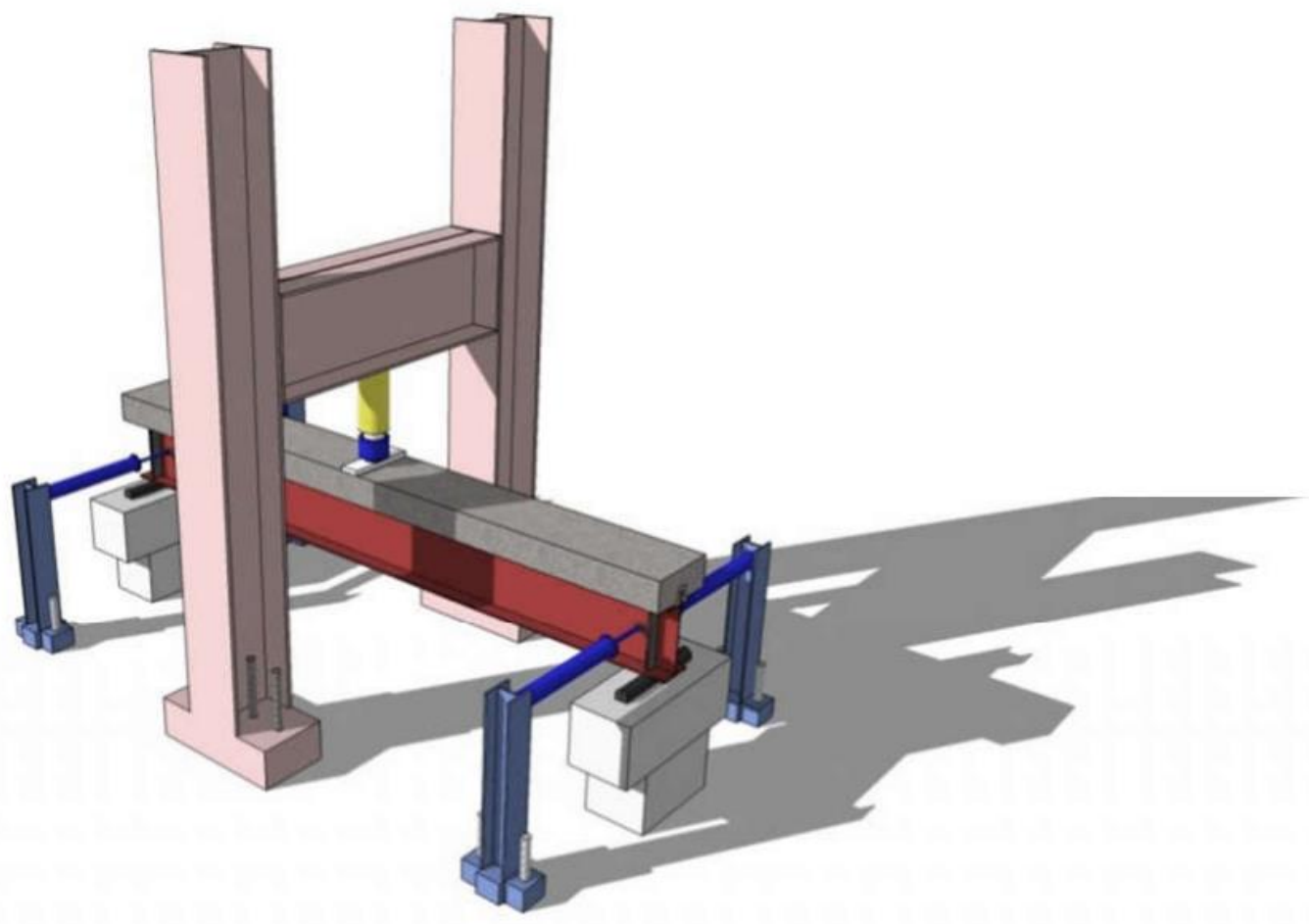

Figure 7 - Overview of test setup.

Diógenes, Hidelbrando J. F., El Debs, Ana Lúcia H. C., Valente, Isabel B. (2018).

Tests on composite beams using new connections by adherence.

Paper submitted to Structures and Buildings, ICE Publishing, Volume 171, Issue 2, February 2018,

Pages 149-165, ISSN 0965-0911 | E-ISSN 1751-7702. 

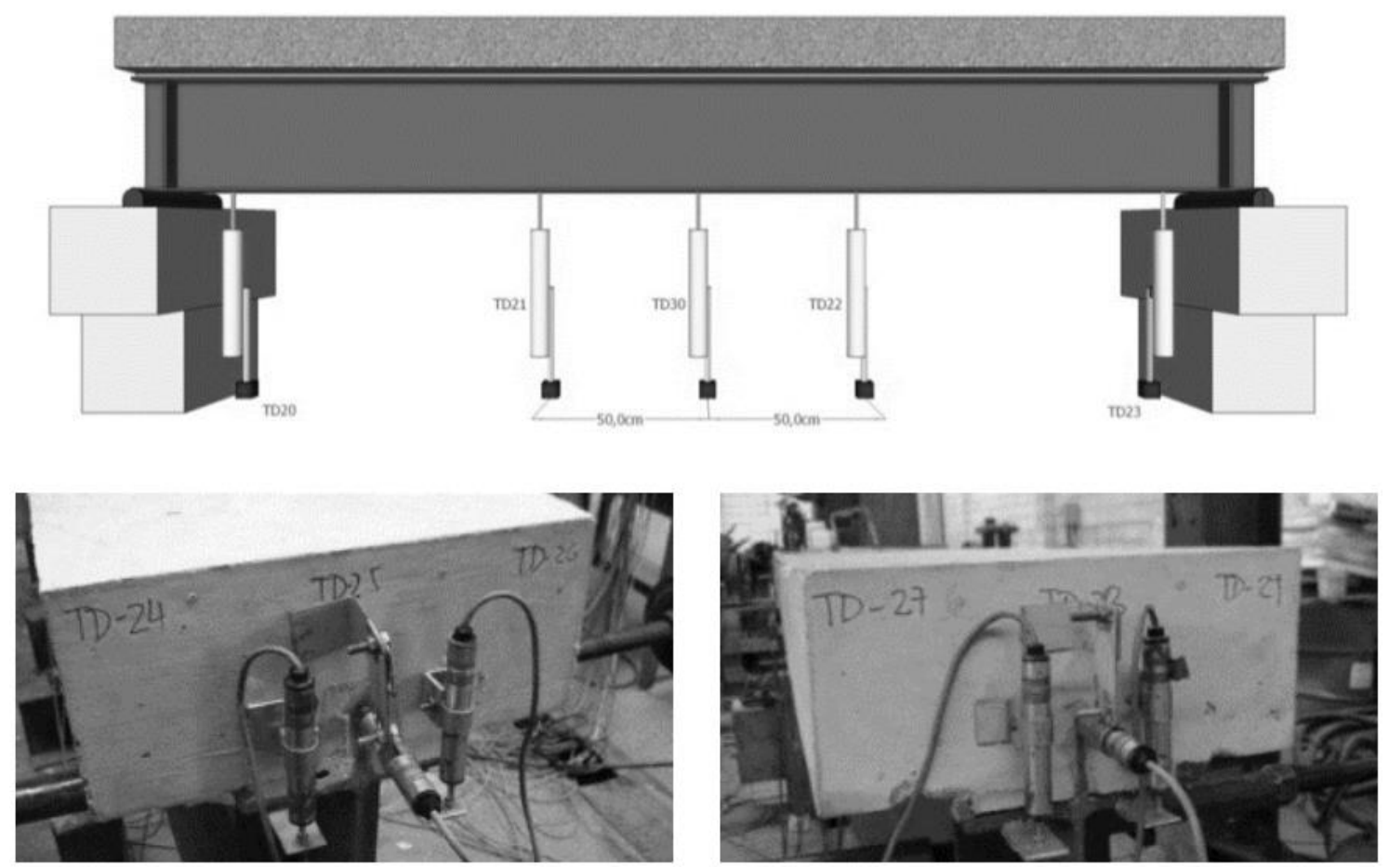

Figure 8 - Transducers position

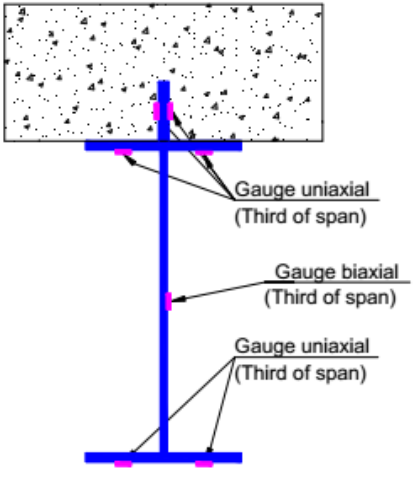

(a)

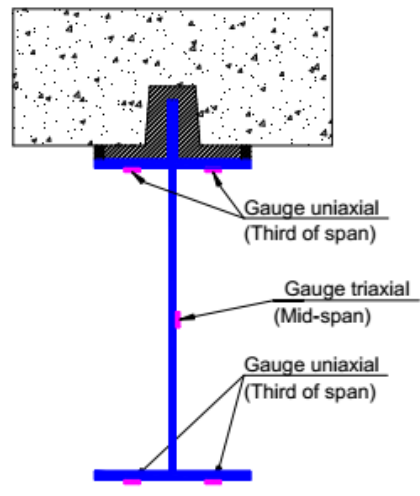

(b)

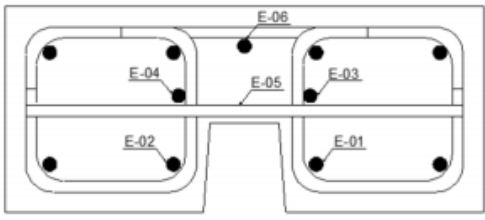

(c)

Figure 9 - Strain gauges positions: (a) Specimens VM-01 and VM-02; (b) Specimens VM-03, VM04, VM-05 and VM-06; (c) Strain gauges of reinforcements at the mid-span of beam.

Diógenes, Hidelbrando J. F., El Debs, Ana Lúcia H. C., Valente, Isabel B. (2018).

Tests on composite beams using new connections by adherence.

Paper submitted to Structures and Buildings, ICE Publishing, Volume 171, Issue 2, February 2018, Pages 149-165, ISSN 0965-0911 | E-ISSN 1751-7702. 


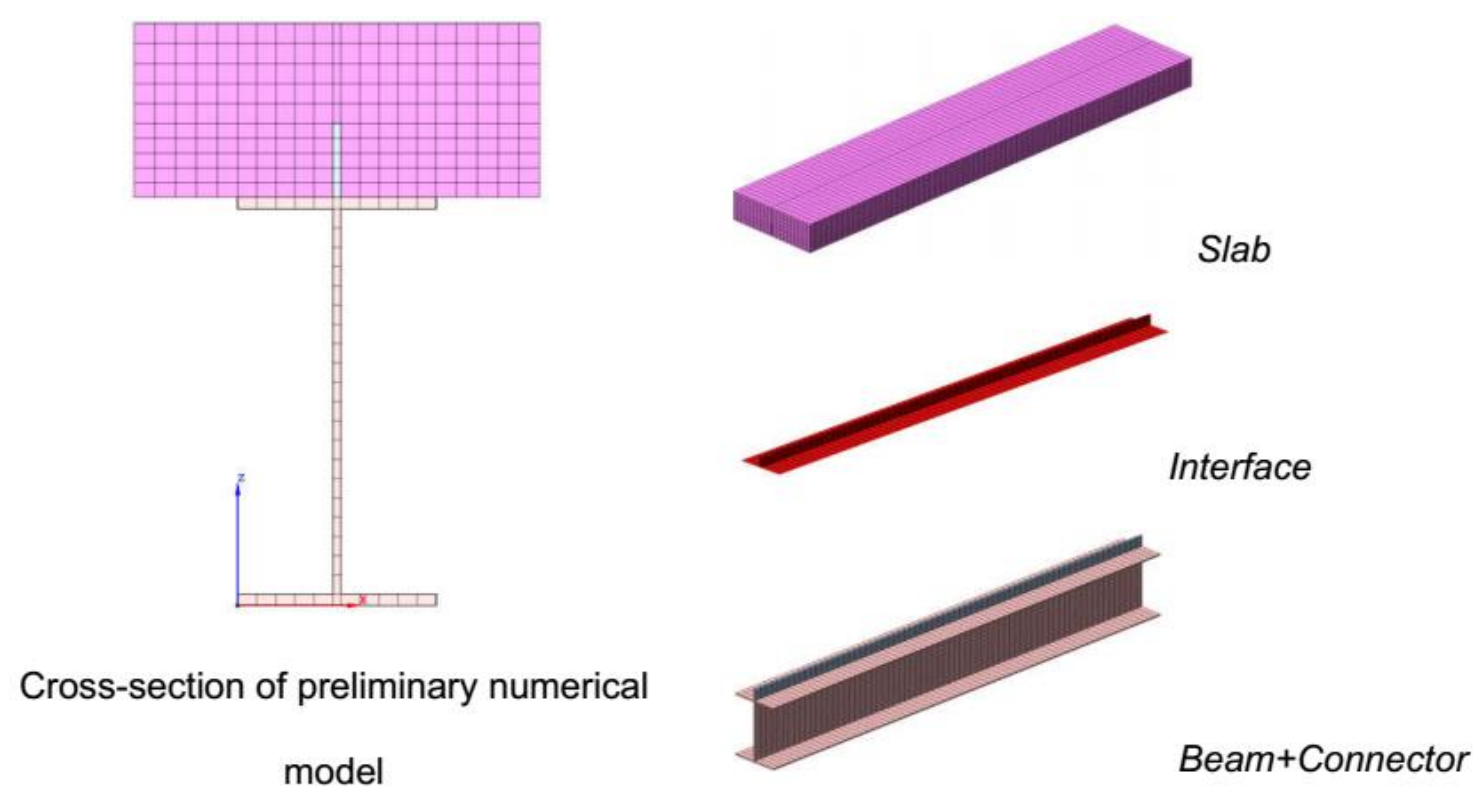

Figure 10 - Cross section and parts of the numerical model.

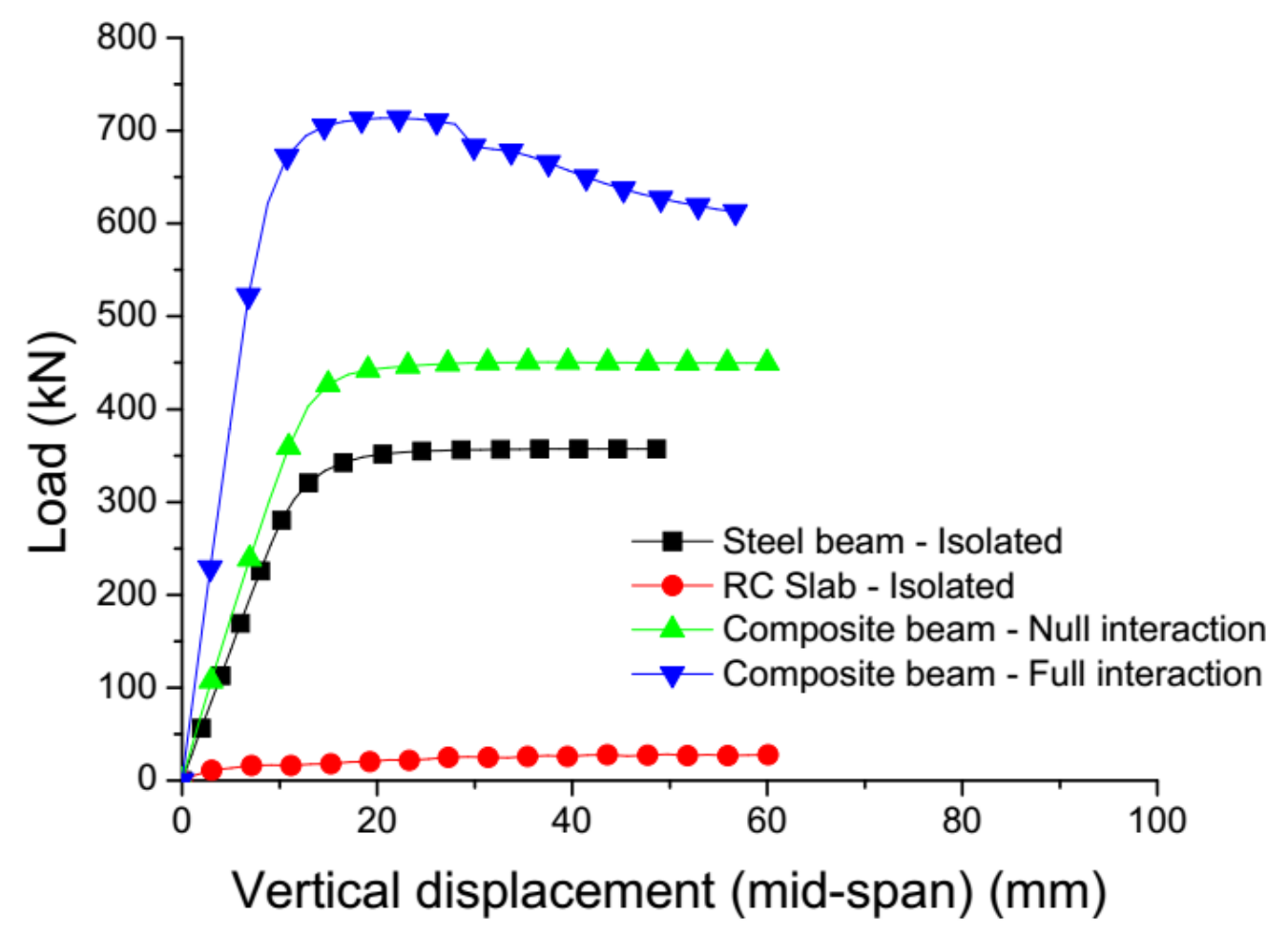

Figure 11 - Load versus displacement result of a preliminary numerical study where both degree of interaction were tested at the resistance of isolated elements are estimated.

Diógenes, Hidelbrando J. F., El Debs, Ana Lúcia H. C., Valente, Isabel B. (2018).

Tests on composite beams using new connections by adherence.

Paper submitted to Structures and Buildings, ICE Publishing, Volume 171, Issue 2, February 2018, Pages 149-165, ISSN 0965-0911 | E-ISSN 1751-7702. 


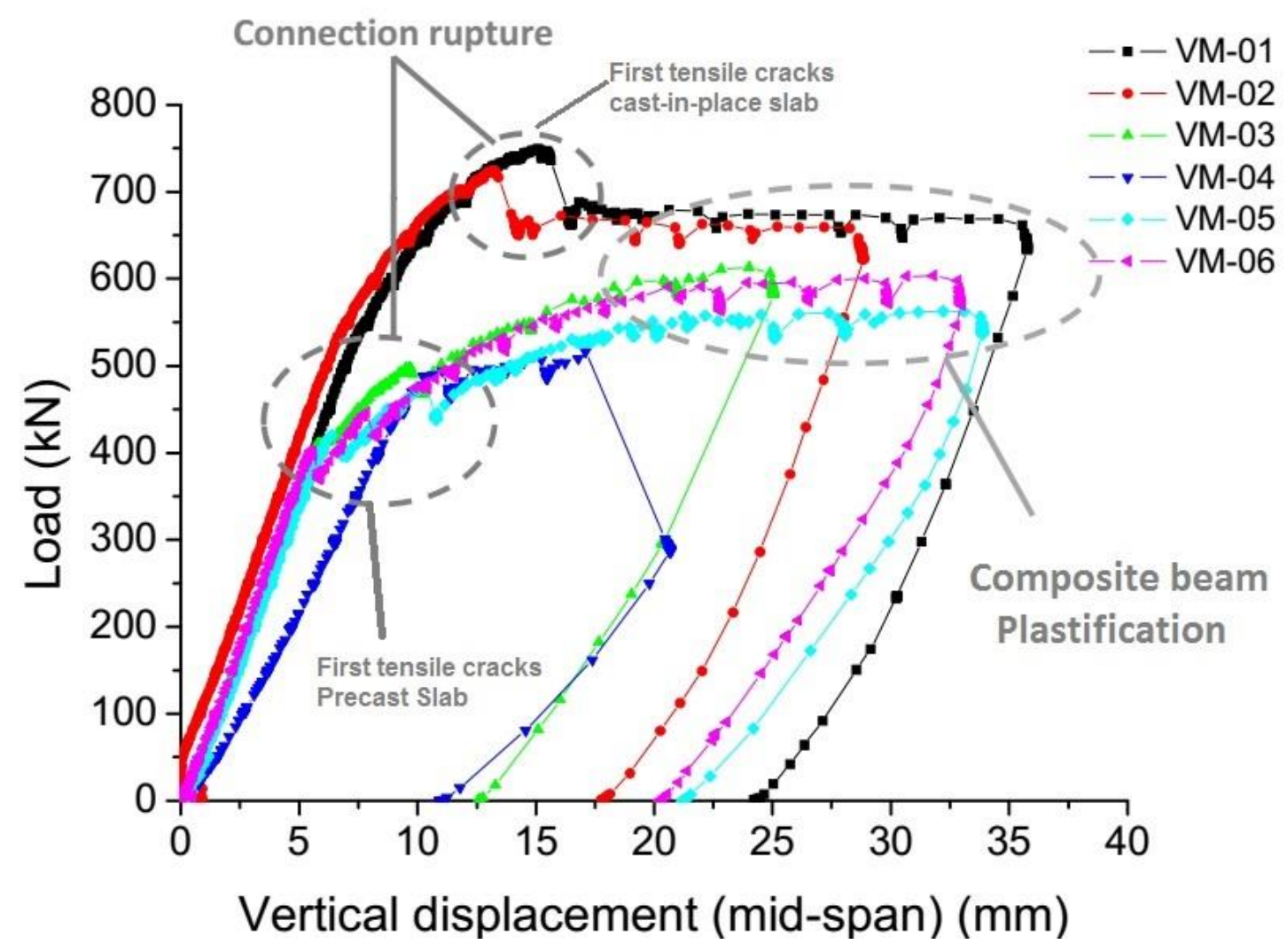

Figure 12 - Specimens results: Load $\times$ Displacement, at the beam's mid-span.

Diógenes, Hidelbrando J. F., El Debs, Ana Lúcia H. C., Valente, Isabel B. (2018).

Tests on composite beams using new connections by adherence.

Paper submitted to Structures and Buildings, ICE Publishing, Volume 171, Issue 2, February 2018,

Pages 149-165, ISSN 0965-0911 | E-ISSN 1751-7702. 


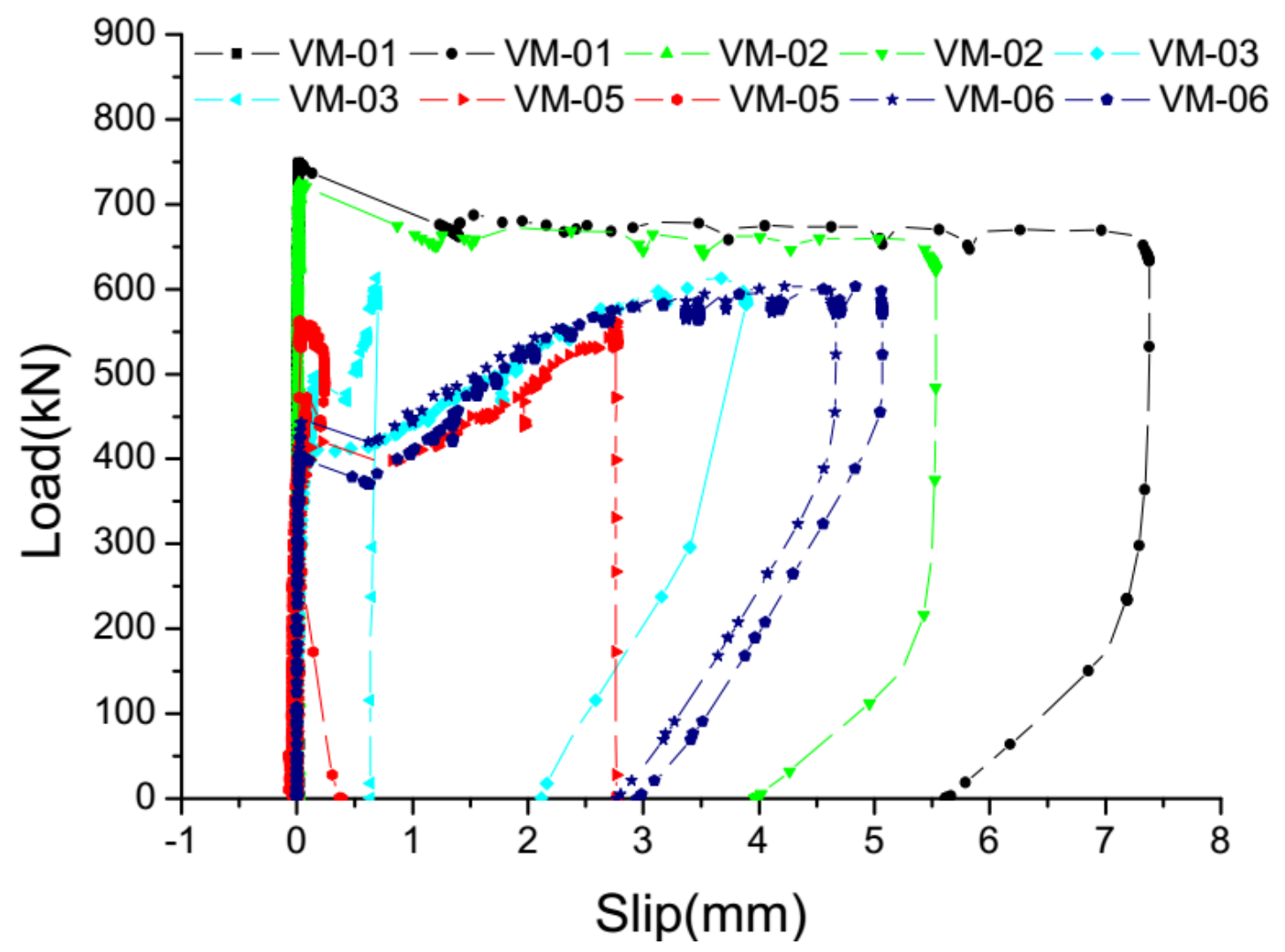

Figure 15 - Load (applied at mid span) x Slip (measured in support).

Diógenes, Hidelbrando J. F., El Debs, Ana Lúcia H. C., Valente, Isabel B. (2018).

Tests on composite beams using new connections by adherence.

Paper submitted to Structures and Buildings, ICE Publishing, Volume 171, Issue 2, February 2018,

Pages 149-165, ISSN 0965-0911 | E-ISSN 1751-7702. 


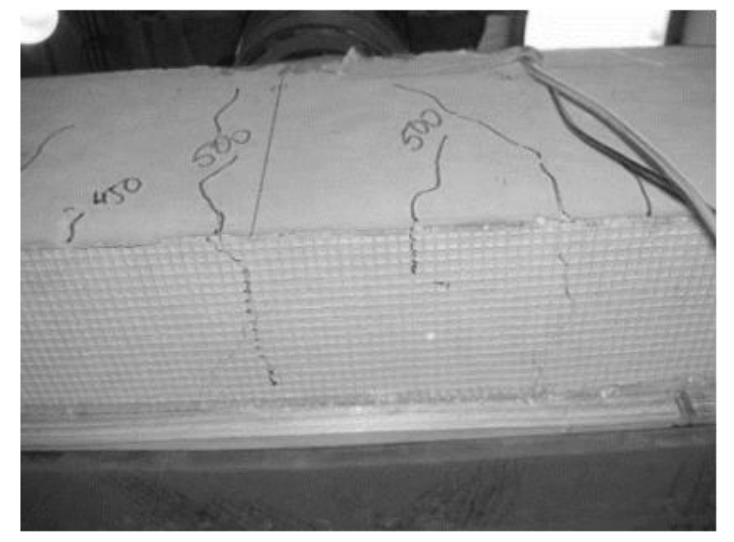

(a)

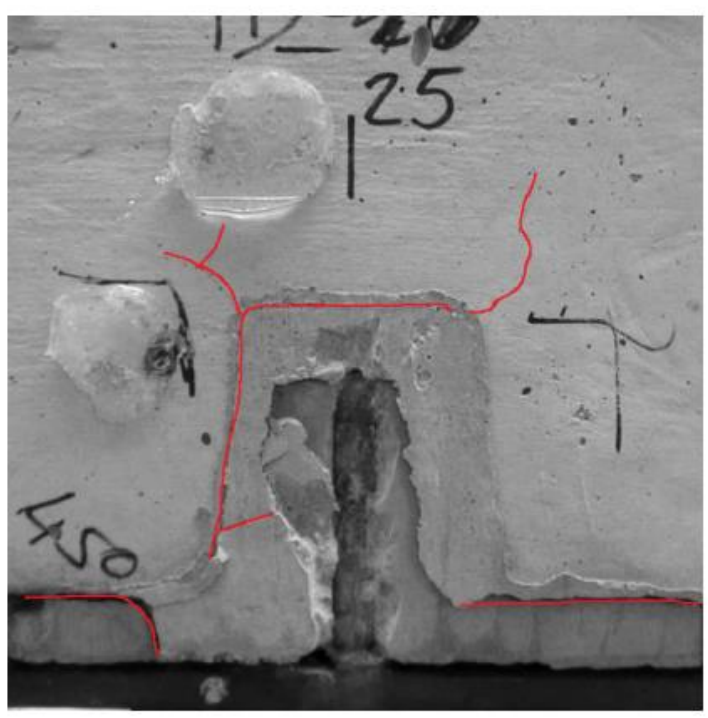

(c)

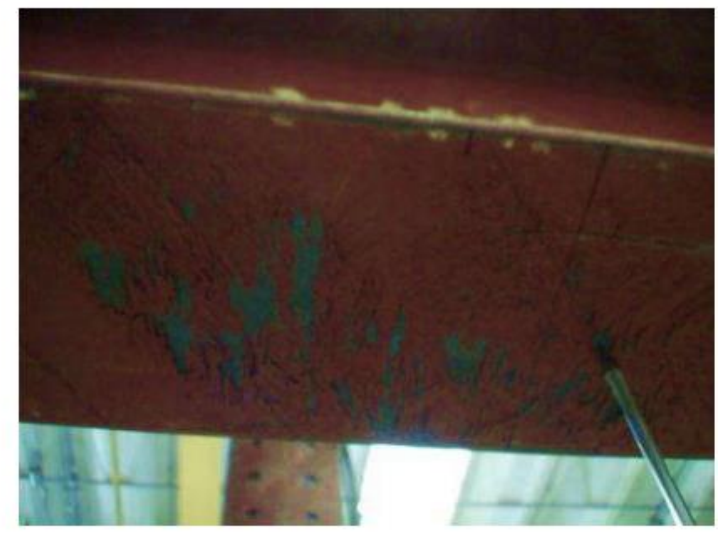

(b)

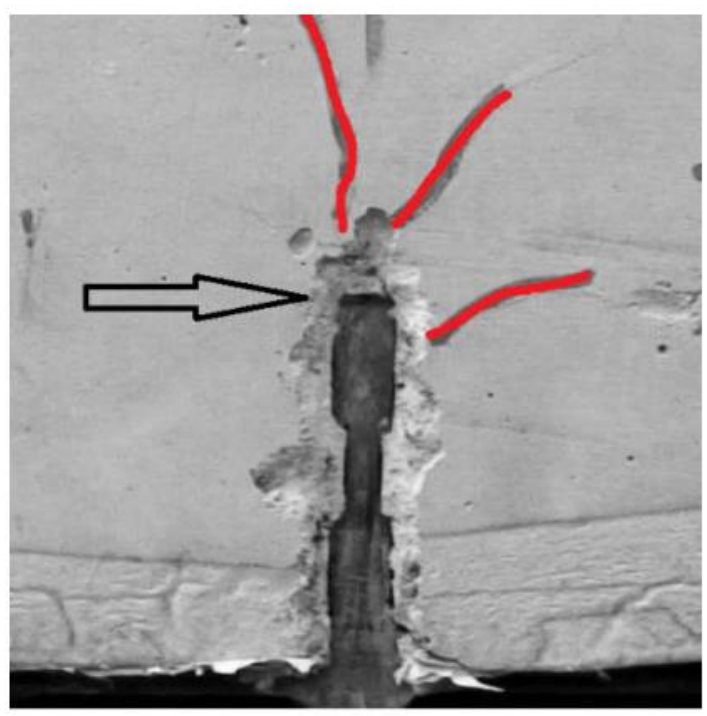

(d)

Figure 164 - Post-peak configuration of the elements of composite section: a) Slab Cracking; (b) Detachment of the protective paint on the bottom flange; (c) Connection region detail - Specimens with precast slab; (d) Connection region detail - Prototype with cast in place slab.

Diógenes, Hidelbrando J. F., El Debs, Ana Lúcia H. C., Valente, Isabel B. (2018).

Tests on composite beams using new connections by adherence.

Paper submitted to Structures and Buildings, ICE Publishing, Volume 171, Issue 2, February 2018, Pages 149-165, ISSN 0965-0911 | E-ISSN 1751-7702. 


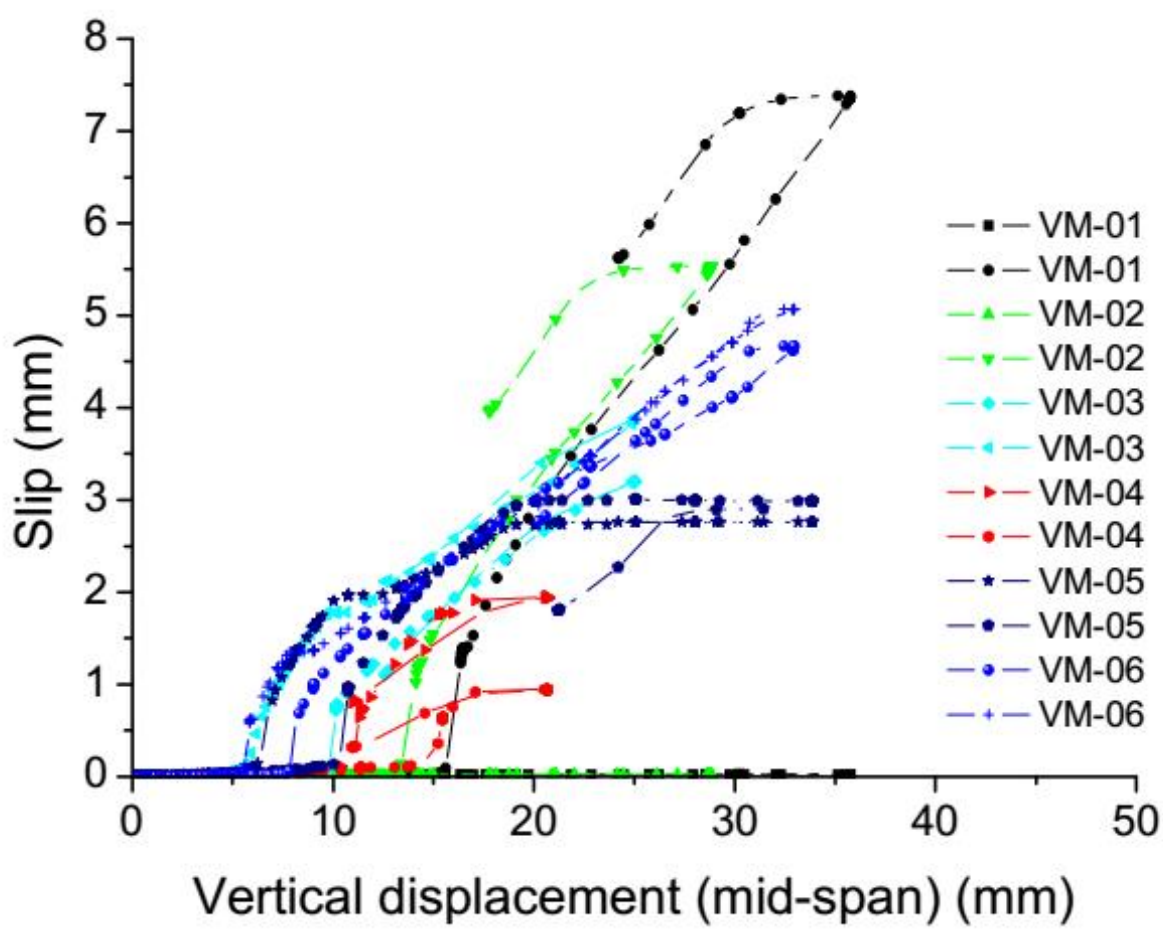

(a)

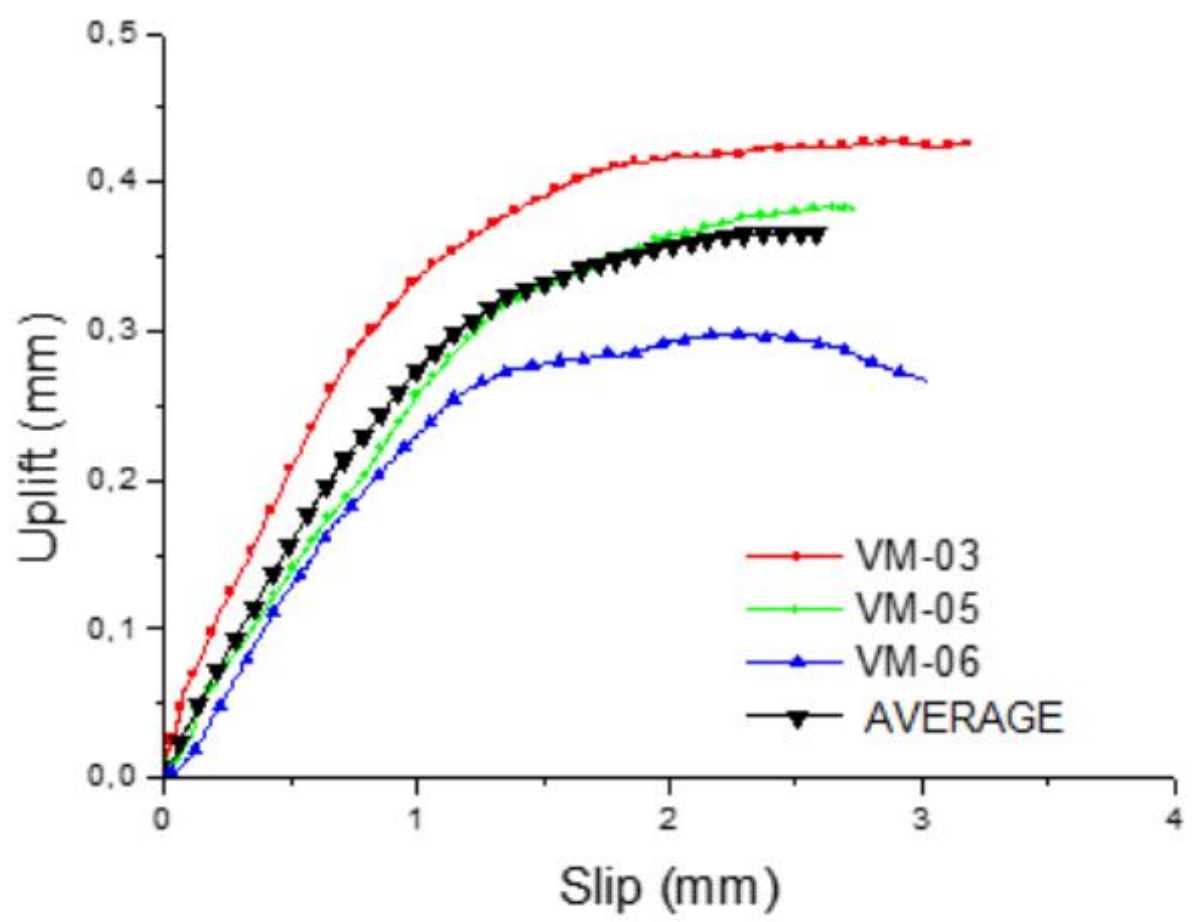

(b)

Figure 15 - (a) Slip versus Vertical displacement (mid-span); (b) Slip versus Uplift (end supports)

Diógenes, Hidelbrando J. F., El Debs, Ana Lúcia H. C., Valente, Isabel B. (2018).

Tests on composite beams using new connections by adherence.

Paper submitted to Structures and Buildings, ICE Publishing, Volume 171, Issue 2, February 2018, Pages 149-165, ISSN 0965-0911 | E-ISSN 1751-7702. 


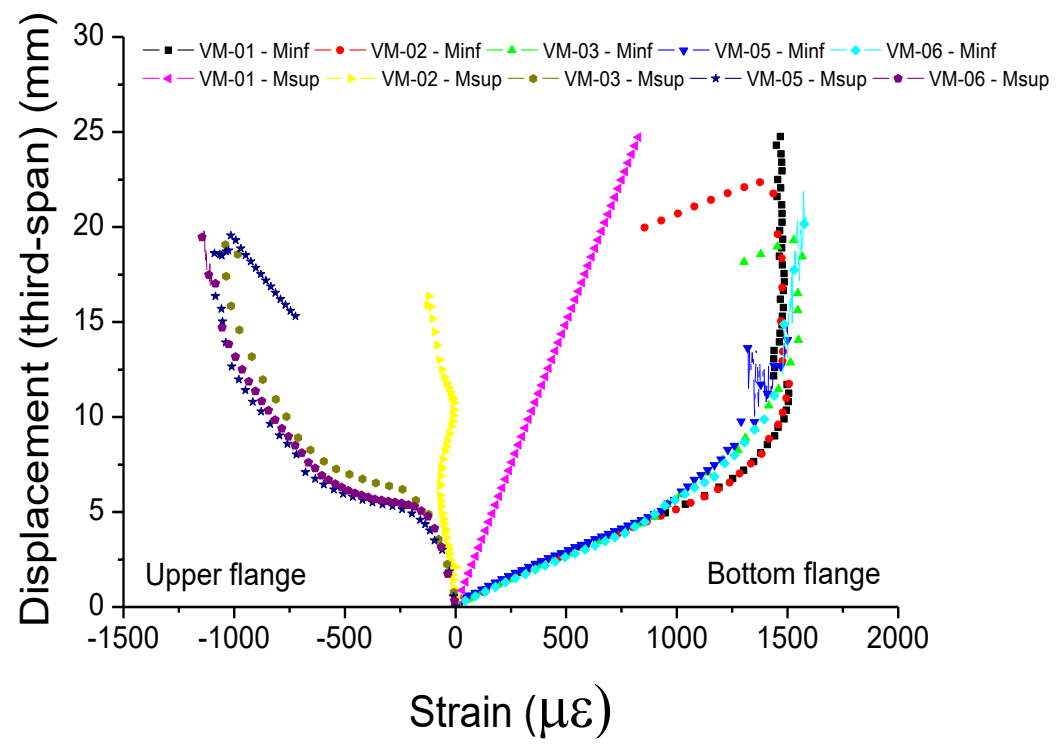

(a)

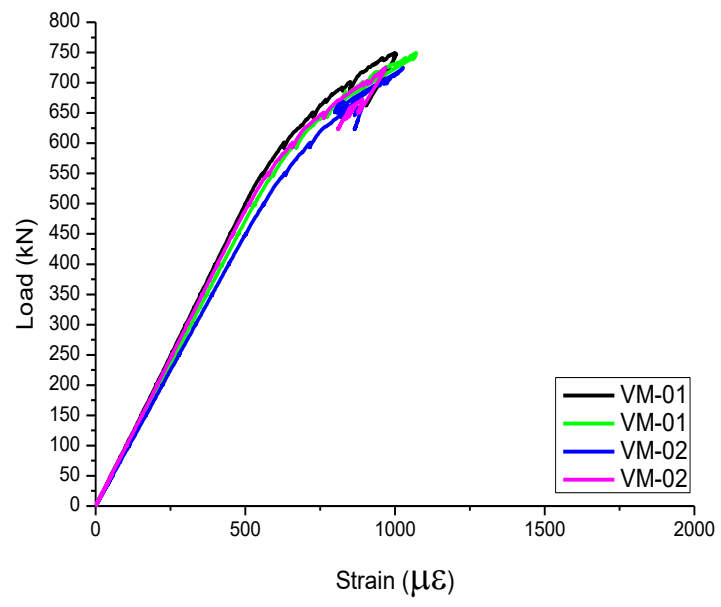

(b)

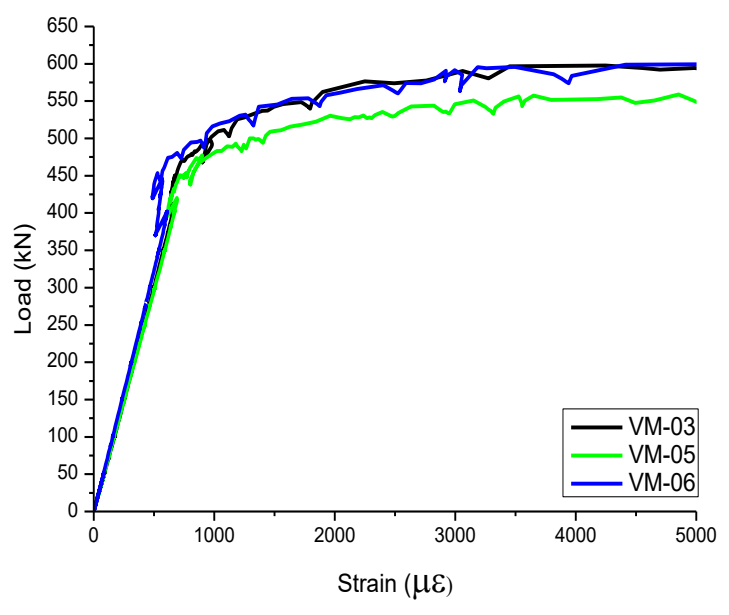

(c)

Figure 17 - Steel beam longitudinal strains patterns. (a) upper and bottom flange for all specimens; (b) half of depth for cast in place specimens measured at the third of spam; (c) half of depth for precast specimens measured at the mid of spam.

Diógenes, Hidelbrando J. F., El Debs, Ana Lúcia H. C., Valente, Isabel B. (2018).

Tests on composite beams using new connections by adherence.

Paper submitted to Structures and Buildings, ICE Publishing, Volume 171, Issue 2, February 2018, Pages 149-165, ISSN 0965-0911 | E-ISSN 1751-7702. 
Table 1 - Summary of geometrical characteristics of composite beams specimens

\begin{tabular}{|c|c|c|c|c|c|c|c|}
\hline \multirow[b]{2}{*}{ Specimen } & \multirow{2}{*}{$\begin{array}{c}\text { Connector } \\
\text { Type }\end{array}$} & \multicolumn{3}{|c|}{ RC Slab } & \multirow[b]{2}{*}{ Beam Profile } & \multirow[b]{2}{*}{$\begin{array}{c}\mathbf{L} \\
(\mathrm{mm})\end{array}$} & \multirow[b]{2}{*}{$\begin{array}{l}\text { Lef } \\
(\mathrm{mm})\end{array}$} \\
\hline & & Type & $\begin{array}{c}\mathbf{h} \\
(\mathrm{mm})\end{array}$ & $\begin{array}{c}\mathbf{b}_{\mathbf{f}} \\
(\mathrm{mm})\end{array}$ & & & \\
\hline VM-01 & RP & Cast & \multirow{6}{*}{150} & \multirow{6}{*}{350} & \multirow{6}{*}{ W 360 x 44} & \multirow{6}{*}{3500} & \multirow{6}{*}{3300} \\
\hline VM-02 & RP & in-place & & & & & \\
\hline VM-03 & $\mathrm{R}$ & \multirow{4}{*}{ Precast } & & & & & \\
\hline VM-04 & $\mathrm{R}$ & & & & & & \\
\hline VM-05 & $\mathrm{RP}$ & & & & & & \\
\hline VM-06 & RP & & & & & & \\
\hline
\end{tabular}

Table 2 - Mechanical properties of used materials

\begin{tabular}{|c|c|c|c|c|c|c|c|c|}
\hline \multirow{2}{*}{ Material } & \multicolumn{2}{|c|}{$f_{c m}(\mathrm{MPa})$} & \multicolumn{2}{|c|}{$E_{c m}(\mathrm{GPa})$} & \multicolumn{2}{|c|}{$f_{t m}(\mathrm{MPa})$} & \multirow{2}{*}{$\begin{array}{c}\text { Age } \\
\text { (days) }\end{array}$} & \multirow{2}{*}{ Specimen } \\
\hline & Average & C.V. & Average & C.V. & Average & C.V. & & \\
\hline Concrete & 37.6 & $11.6 \%$ & 35.29 & $2.5 \%$ & 3.20 & $23.3 \%$ & 58 & VM-01 to \\
\hline HPM & 94.0 & $2.9 \%$ & 29.53 & $1.9 \%$ & 2.90 & $27.2 \%$ & 35 & VM-06 \\
\hline $\begin{array}{l}\text { Steel - } \\
\text { Bars }\end{array}$ & \multicolumn{8}{|c|}{$\boldsymbol{f}_{y}=500 \mathrm{MPa} ; \boldsymbol{E}_{\boldsymbol{s}}=200 \mathrm{GPa}$ (nominal values) } \\
\hline \multirow{4}{*}{$\begin{array}{l}\text { Steel - } \\
\text { Beam }\end{array}$} & \multicolumn{2}{|c|}{ Specimen } & & & Average & C.V. & & \\
\hline & \multicolumn{2}{|c|}{$\begin{array}{c}V M-01, V M-02 \\
\text { and VM-03 }\end{array}$} & $\begin{array}{l}f_{u} \\
f_{y}\end{array}$ & $\begin{array}{l}\text { (MPa) } \\
(\mathrm{MPa})\end{array}$ & $\begin{array}{l}502.6 \\
392.0\end{array}$ & $\begin{array}{l}1.3 \% \\
3.8 \%\end{array}$ & & \\
\hline & \multicolumn{2}{|c|}{$\begin{array}{c}\text { VM-03, VM-04 } \\
\text { and VM-06 }\end{array}$} & $\begin{array}{l}f_{u} \\
f_{y}\end{array}$ & $\begin{array}{l}\text { (MPa) } \\
(\mathrm{MPa})\end{array}$ & $\begin{array}{l}498.5 \\
386.5\end{array}$ & $\begin{array}{l}1.0 \% \\
3.5 \%\end{array}$ & & \\
\hline & \multicolumn{2}{|c|}{$\begin{array}{l}\text { VM-01 to VM-06 } \\
\text { (connector) }\end{array}$} & $\begin{array}{l}\boldsymbol{f}_{u} \\
\boldsymbol{f}_{y}\end{array}$ & $\begin{array}{l}\mathrm{MPa}) \\
(\mathrm{MPa}) \\
\end{array}$ & $\begin{array}{l}475.7 \\
329.6 \\
\end{array}$ & $\begin{array}{l}1.1 \% \\
2.7 \% \\
\end{array}$ & & \\
\hline
\end{tabular}

Notes: ASTM - A36 (connector); ASTM - A572 G50 (beam); CA-50 (RC bars)

Diógenes, Hidelbrando J. F., El Debs, Ana Lúcia H. C., Valente, Isabel B. (2018).

Tests on composite beams using new connections by adherence.

Paper submitted to Structures and Buildings, ICE Publishing, Volume 171, Issue 2, February 2018, Pages 149-165, ISSN 0965-0911 | E-ISSN 1751-7702. 
Table 3 - Maximum flexural strength

\begin{tabular}{|c|c|c|c|c|c|c|}
\hline \multirow[t]{2}{*}{ Specimen } & $\begin{array}{c}\text { Maximum } \\
\text { applied } \\
\text { load }\end{array}$ & $\begin{array}{c}\text { Average } \\
\text { maximum } \\
\text { load }\end{array}$ & $\begin{array}{c}\text { Maximum } \\
\text { bending } \\
\text { moment, } \\
\text { at mid } \\
\text { span } \\
\end{array}$ & $\begin{array}{c}\text { Average } \\
\text { maximum } \\
\text { bending } \\
\text { moment, at } \\
\text { mid span }\end{array}$ & $\begin{array}{c}\text { Mid-span } \\
\text { vertical } \\
\text { Displacement } \\
\text { for maximum } \\
\text { load } \\
\end{array}$ & $\begin{array}{l}\text { Flexural } \\
\text { stiffness }\end{array}$ \\
\hline & (kN) & $(\mathrm{kN})$ & (kN.m) & (kN.m) & $(\mathrm{mm})$ & (kN.m/rad) \\
\hline VM-01 & 747.31 & \multirow{2}{*}{736.02} & 616.53 & \multirow{2}{*}{607.22} & 15.46 & \multirow{2}{*}{426.78} \\
\hline VM-02 & 724.73 & & 597.90 & & 13.15 & \\
\hline VM-03 & 613.17 & \multirow{2}{*}{564.67} & 505.86 & \multirow{2}{*}{465.83} & 24.02 & \multirow{2}{*}{306.56} \\
\hline VM-04* & 516.35 & & 425.90 & & 17.09 & \\
\hline VM-05 & 603.22 & \multirow{2}{*}{582.92} & 497.65 & \multirow{2}{*}{480.91} & 31.78 & \multirow{2}{*}{332.85} \\
\hline VM-06 & 562.62 & & 464.16 & & 32.21 & \\
\hline
\end{tabular}

* Specimen presented web crippling

Diógenes, Hidelbrando J. F., El Debs, Ana Lúcia H. C., Valente, Isabel B. (2018).

Tests on composite beams using new connections by adherence.

Paper submitted to Structures and Buildings, ICE Publishing, Volume 171, Issue 2, February 2018, Pages 149-165, ISSN 0965-0911 | E-ISSN 1751-7702. 